\title{
Online Synchronous Clinical Communication Training During the COVID-I9 Pandemic [Letter]
}

This article was published in the following Dove Press journal:

Advances in Medical Education and Practice

\section{Agatha Bebbington \\ Alan Hasanic}

Department of Medicine, Imperial

College London, London, SW7 2BU, UK
Correspondence: Agatha Bebbington Email amb220@ic.ac.uk

\section{Dear editor}

We read with interest the work of Perron et al evaluating the use of online synchronous clinical communications teaching during the COVID-19 pandemic. ${ }^{1}$ As 5th year medical students in the UK we understand the challenges of delivering online synchronous tutorials. Immediate innovation is needed to ensure that medical education is not compromised. Therefore, we praise Perron et al for their pressing interest in this issue.

The rapid implementation of online training for tutors in Geneva is commendable. However, at medical schools employing busy clinicians as tutors, replicating this efficiency was unachievable in the early pandemic period. UK medical students reported that only $28.48 \%$ had access to live online tutorials. ${ }^{2}$ We therefore disagree with the conclusion drawn by Perron et al, as not all tutors can quickly adapt to online teaching. Innovation that combines clinical work and teaching is critical to solving this problem. Virtual ward rounds using smart glasses have been successful in giving junior doctors guidance during the COVID-19 pandemic. ${ }^{3}$ Similar technology could allow students to witness communication skills in action, whilst not detracting from the work of clinicians.

The advantage of reduced travel time presented by Perron et al strongly resonates with us. UK medical students report saving time on travelling as a major advantage of online learning. ${ }^{2}$ From our experience, increased time efficiency has revealed opportunities to be taught by international experts, who were previously unable to commit to teaching. This key advantage of online communication skills should be included in a blended post-pandemic curriculum.

Medical students worldwide have volunteered in the crisis response, ${ }^{4}$ thus we were unsurprised to see this listed as a reason for absence from online teaching. UK medical students report inconvenient tutorial timings as a hindrance to successful online learning. ${ }^{2}$ At our university, international students describe difficulty in attending live lectures due to time differences. Although online teaching teases greater flexibility for students, fair distribution of learning resources are compromised. To ensure just dissemination of teaching, a distinction must be made between topics suited to asynchronous learning, and those resolutely requiring faceto-face teaching.

The student feedback collected based on a 4-week time frame at the beginning of the pandemic, is a limitation in the work of Perron et al. The student's outlook is likely to have been inflated as they had not yet "tired" of online teaching. In 
addition, the teaching sessions assessed by Perron et al included topics that lent themselves to online learning. Sensitive teaching themes such as "breaking bad news" may have not produced such positive feedback. In light of this, we agree with Perron et al that online teaching cannot completely replace face-to-face experience. Encouraging volunteering on hospital wards is a long-term solution, which offers opportunities to learn communication skills through the mentorship of doctors. ${ }^{5}$

Perron et al highlight the success of synchronous clinical communication skills teaching during the early COVID-19 pandemic. However, a sustainable approach should utilise a blended curriculum, including face-toface patient contact as well as asynchronous and synchronous online learning.

\section{Disclosure}

The authors report no conflicts of interest in this communication.

\section{References}

1. Junod Perron N, Dominicé Dao M, Rieder A, Sommer J, Audétat M-C. Online synchronous clinical communication training during the covid-19 pandemic. Adv Med Educ Pract. 2020;11:1029-1036. doi:10.2147/AMEP.S286552

2. Dost S, Hossain A, Shehab M, Abdelwahed A, Al-Nusair L. Perceptions of medical students towards online teaching during the COVID-19 pandemic: a national cross-sectional survey of $2721 \mathrm{UK}$ medical students. BMJ Open. 2020;10(11):e042378. doi:10.1136/ bmjopen-2020-042378

3. Munusamy T, Karuppiah R, Bahuri NFA, Sockalingam S, Cham CY, Waran V. Telemedicine via smart glasses in critical care of the neurosurgical patient-COVID-19 pandemic preparedness and response in neurosurgery. World Neurosurg. 2021;145:e53-e60. doi:10.1016/j. wneu.2020.09.076

4. Mahase E. Covid-19: medical students to be employed by NHS as part of epidemic response. BMJ. 2020;368:m1156. doi:10.1136/bmj.m1156

5. Choi B, Jegatheeswaran L, Minocha A, Alhilani M, Nakhoul M, Mutengesa E. The impact of the COVID-19 pandemic on final year medical students in the United Kingdom: a national survey. BMC Med Educ. 2020;20(1):206. doi:10.1186/s12909-020-02117-1

Dove Medical Press encourages responsible, free and frank academic debate. The content of the Advances in Medical Education and Practice 'letters to the editor' section does not necessarily represent the views of Dove Medical Press, its officers, agents, employees, related entities or the Advances in Medical Education and Practice editors. While all reasonable steps have been taken to confirm the content of each letter, Dove Medical Press accepts no liability in respect of the content of any letter, nor is it responsible for the content and accuracy of any letter to the editor.

\section{Publish your work in this journal}

Advances in Medical Education and Practice is an international, peerreviewed, open access journal that aims to present and publish research on Medical Education covering medical, dental, nursing and allied health care professional education. The journal covers undergraduate education, postgraduate training and continuing medical education including emerging trends and innovative models linking education, research, and health care services. The manuscript management system is completely online and includes a very quick and fair peer-review system. Visit http://www.dovepress.com/testimonials.php to read real quotes from published authors. 